www.jmscr.igmpublication.org

Impact Factor 5.84

Index Copernicus Value: 71.58

ISSN (e)-2347-176x ISSN (p) 2455-0450

crossref DOI: _https://dx.doi.org/10.18535/jmscr/v5i10.35

Journal Of Medical Science And Clinical Research

\title{
Comparison of Obstructive Sleep Apnea Characteristics in Obese and Non- Obese Subjects by Anthropometric and Polysomnographic Data
}

Authors

\author{
Dr K.Surendar Reddy ${ }^{1}$, Dr V.Chetan Rao ${ }^{2}$, Dr J.Sowmya ${ }^{3}$, Dr Pradyut Waghray ${ }^{4}$ \\ ${ }^{1}$ Associate Professor, Department of Pulmonary Medicine, SVS Medical College, Mahabubnagar, Telangana \\ ${ }^{2}$ Senior Resident, Govt General \&Chest Hospital, Osmania Medical College, Hyderabad \\ ${ }^{3}$ Assistant Professor, Department of Pulmonary Medicine, Mamatha Medical college, Khammam \\ ${ }^{4}$ Prof \& HOD, Department of Pulmonary Medicine, SVS Medical College, Mahabubnagar, Telangana
}

Corresponding Author

Dr K.Surendar Reddy

Associate Professor, Dept of Pulmonary Medicine SVS Medical College \&Hospital, Mahabubnagar,

Telangana

Contact number: 9949316154, Email: surendark918@gmail.com

\begin{abstract}
Objective: To compare the anthropometric and polysomnographic data between obese and non-obese subjects with obstructive sleep apnea (OSA).

Materials and Methods: A prospective parallel group comparative study was conducted by analyzing the anthropometric and polysomnographic data in 50 subjects with suspected OSA who underwent a sleep study from October 2013 to September 2015. Of these, 25 patients were obese (body mass index [BMI] $\geq 30 \mathrm{~kg} / \mathrm{m}^{2}$ ) and 25 were not $\left(B M I<30 \mathrm{~kg} / \mathrm{m}^{2}\right)$. The anthropometric and polysomnographic data were evaluated and compared between the two groups using either chi-squared tests or unpaired t-tests.

Results: After study completion, 39 subjects (78\%; 17 non-obese and 22 obese) were diagnosed with OSA (apnea-hypopnea index $[A H I] \geq 5$ ). The mean AHI per hour was significantly higher in obese than in nonobese subjects $(67.6 \pm 28.6$ vs. $16.7 \pm 5.99$, P value 0.000). Anthropometric measurements were significantly higher in obese than in non-obese subjects with OSA. Moreover, the Epworth Sleepiness Scale, arousal index, and snoring index scores were significantly higher in obese than in non-obese subjects with OSA. The oxygen desaturation parameters, total sleep time, sleep efficiency, and N3 and rapid-eye movement stages of sleep were significantly decreased in obese subjects compared to in non-obese subjects with OSA. Overall, the OSA in obese subjects was more severe compared to that in non-obese subjects.

Conclusion: OSA was more common in obese than in non-obese subjects; however, some non-obese subjects also had OSA. This finding contrasts with theories suggesting OSA is confined only to obese subjects. Therefore, when a non-obese person presents with the clinical characteristics of OSA, the diagnostic possibility should not be underestimated and should be evaluated thoroughly.

Keywords: body mass index, obesity, obstructive sleep apnea, apnea-hypopnea index.
\end{abstract}




\section{Introduction}

Obstructive sleep apnea (OSA) is defined as the cessation of airflow for more than $10 \mathrm{~s}$, despite continuing ventilatory effort, for five or more times per hour of sleep, and is usually associated with a decrease in arterial oxygen saturation $(\mathrm{SaO} 2)$ of more than $4 \% .{ }^{[1]}$ The prevalence of OSA varies worldwide, as presented in Table 1.

Obesity is a well-recognized risk factor for a variety of medical conditions including OSA. ${ }^{[2]}$ Globally, between 1980 and 2013, the proportion of adults with a body mass index (BMI) of 25 $\mathrm{kg} / \mathrm{m}^{2}$ or greater increased from $28.8 \%(95 \%$ uncertainty interval [UI]: $28.4-29.3)$ to $36.9 \%$ (95\% UI: $36 \cdot 3-37.4$ ) in men, and from $29.8 \%$ (95\% UI: $29 \cdot 3-30 \cdot 2$ ) to $38.0 \%$ (95\% UI: $37 \cdot 5-$ $38 \cdot 5)$ in women. ${ }^{[3]}$ Studies show that nearly 60 $90 \%$ of patients with OSA are obese. ${ }^{[4,5]}$ Nonobese people can also have OSA, but the occurrence of OSA in non-obese patients may be related to different structural abnormalities than those found in obese patients with OSA. ${ }^{[6,7]}$

The American Academy of Sleep Medicine (AASM) recommends performing polysomnography to determine the severity of sleep apnea and to evaluate the patient's response to treatment. ${ }^{[8]}$ However, data regarding the prevalence and characteristics of OSA among non-obese patients is scarce, and the OSA in nonobese patients may exhibit different characteristics than the OSA in obese patients. Therefore, the present study was designed to compare the anthropometric and polysomnographic data between obese and non-obese patients with OSA.

\section{Materials and Methods}

This prospective parallel group comparative study was conducted for a period of two years (October 2013 to September 2015) in order to evaluate and compare the characteristics of OSA between obese and non-obese subjects. This study was conducted after approval by the local research ethics committee. All subjects gave informed consent to participate in the study.

\section{Subjects}

Fifty individuals suspected of having OSA were enrolled in the present study. Of these, 25 were obese and 25 were non-obese. The inclusion criteria were as follows: males and females, age $>15$ years, $\mathrm{BMI} \geq 18.5$, history of snoring, and Epworth Sleepiness Scale (ESS) score $\geq 10$. Subjects were excluded if they had any of the following: pulmonary tuberculosis, chronic obstructive pulmonary disease, bronchial asthma, interstitial lung disease, neuromuscular disorders, history of drug abuse, chronic renal failure, congestive heart failure, pregnant, or receiving treatment for psychiatric conditions.

\section{Evaluations}

ESS: ${ }^{[9]}$ We used ESS to provide a subjective assessment of excessive daytime sleepiness

Anthropometric measurements: The following data were collected from each subject:_BMI, neck circumference, waist circumference, hip circumference, thyromental distance, and Mallampati score. ${ }^{[10]}$

Polysomnographic recordings: ${ }^{[11]}$ All subjects underwent a sleep study consisting of an overnight polysomnographic examination. During the examination the following items were recorded: electroencephalograms (C3-A2, C4-A1, O2-A1, and $\mathrm{O} 3-\mathrm{A} 2$ ), bilateral electrooculograms, chin and lower leg electromyograms, nasal and mouth airflow, thoracic and abdominal respiratory movements, electrocardiograms, and oxygen saturation measured by finger oximetry. For this study, a computerized polysomnography machine manufactured by Recorders and Medicare Systems, with 16 channel inputs, was used.

All 50 individuals were subjected to an 8-h, overnight polysomnography. Polysomnographic recording was performed from 22:00 to 06:00. All of the subjects were asked to empty their bladder before the recording. Before applying the electrodes, the skin was prepared with spirit. 
Polysomnographic data, including the sleep stages, snoring index, arousal index, oxygen saturation parameters, and abnormal movements were scored manually .

Sleep apnea severity: ${ }^{[12]}$ The severity of sleep apnea was assessed with the apnoea-hypopnoea index (AHI), which counts the number of apneas and hypopneas per hour of sleep. According to the AASM recommendations, OSA is defined as an $\mathrm{AHI} \geq 5$, and is classified as follows: mild OSA, AHI of 5 to 15; moderate OSA, AHI of 16 to 30; and severe OSA, AHI of $>30$. In the present study, subjects were diagnosed with OSA if their AHI was $\geq 5$ events/h.

After completion of polysomnography, a total of 39 subjects had AHIs $\geq 5$ and were diagnosed with OSA. These 39 (17 non-obese and 22 obese) subjects with OSA were included in the study and final analysis after fulfilling the abovementioned criteria.

\section{Statistical Analysis}

The anthropometric and polysomnographic data were evaluated and compared between the two groups. Data were analyzed using the Statistical Package For the Social Sciences (SPSS Version 16.0). Comparisons of continuous normal data between the two groups were performed using unpaired $t$-tests while comparisons for continuous non-normal data/ordinal data were performed using Wilcoxon rank-sum tests. The association between two variables for categorical data was examined using chi-squared tests. Continuous data are presented as the mean and standard deviation. Ordinal data are presented as the median and inter-quartile range. Categorical data are presented as counts and percentages. $P$ values of less than 0.05 were considered statistically significant.

\section{Results}

Obstructive sleep apnea was diagnosed in 39 of the 50 subjects (78\%). Of these, 17 (68\%) subjects were non-obese and 22 (88\%) were obese. The anthropometric data and the results of the comparisons between the groups are summarized in Table 2. Statistically significant differences in the anthropometric measurements, including the BMI, thyromental distance, and circumferences of the neck, waist, and hip, were observed between non-obese and obese subjects with OSA, with these measures being significantly higher in the obese group than in the non-obese group. Eight (47.1\%) non-obese and $11(50 \%)$ obese subjects with OSA had Class III Mallampati scores.

In addition, we found statistically significant differences in the mean ESS scores between the groups, with obese subjects with OSA having a higher mean ESS than non-obese subjects with OSA. Table 3 summarizes the polysomnographic data for each group and shows the results of the comparisons between the two groups. The snoring and arousal indexes were significantly increased in obese subjects compared to in non-obese subjects with OSA. Eight $(47.1 \%)$ of the nonobese subjects had moderate OSA and 19 (86.4\%) of the obese subjects had severe OSA. Notably, we found that the OSA severity increased with the level of obesity. The oxygen desaturation measurements were significantly higher in obese subjects than in non-obese subjects with OSA. Moreover, statistically significant decreases in the total sleep time and sleep efficiency were observed in obese subjects with OSA compared to in non-obese subjects with OSA. The sleep stages were also significantly decreased in the obese subjects with OSA compared to in the non-obese subjects with OSA. 
Table 1: Prevalence of obstructive sleep apnea in different studies

\begin{tabular}{|c|c|c|c|c|}
\hline Study & Number of subjects & $\mathrm{AHI} \geq 5$ & $\mathrm{AHI} \geq 15$ & OSA \\
\hline $\begin{array}{l}\text { Wisconsin, USA } \\
1993^{[13]}\end{array}$ & $\begin{array}{c}\text { Men: } 352 \\
\text { Women: } 250 \\
\text { (Age: } 30-60 \text { years) }\end{array}$ & $\begin{array}{l}\text { Men: } 24 \% \\
\text { Women: 9\% }\end{array}$ & $\begin{array}{c}\text { Men: } 9 \% \\
\text { Women: } 4 \%\end{array}$ & $\begin{array}{c}\text { Men: } 4 \% \\
\text { Women: } 2 \%\end{array}$ \\
\hline $\begin{array}{l}\text { Pennsylvania, USA } \\
1998,2001^{[15,16]}\end{array}$ & $\begin{array}{c}\text { Men: } 741 \\
\text { Women: } 1000 \\
\text { (Age: } 20-100 \text { years) }\end{array}$ & $\begin{array}{l}\text { Men: 17\% } \\
\text { Women: 5\% }\end{array}$ & $\begin{array}{c}\text { Men: } 7 \% \\
\text { Women: } 2 \%\end{array}$ & $\begin{array}{c}\text { Men: } 3.3 \% \\
\text { Women: } 1.2 \%\end{array}$ \\
\hline Spain $2001^{[14]}$ & $\begin{array}{c}\text { Men: } 325 \\
\text { Women: } 235 \\
\text { (Age: } 30-70 \text { years) }\end{array}$ & $\begin{array}{c}\text { Men: } 26 \% \\
\text { Women: } 28 \%\end{array}$ & $\begin{array}{c}\text { Men: } 14 \% \\
\text { Women: } 7 \%\end{array}$ & $\begin{array}{c}\text { Men: } 3.4 \% \\
\text { Women: 3\% }\end{array}$ \\
\hline Australia $1995^{[17]}$ & $\begin{array}{c}\text { Men: } 294 \\
\text { (Age: } 40-65 \text { years) }\end{array}$ & Men: $25.9 \%$ & Men: $10 \%$ & Men: $3.1 \%$ \\
\hline $\begin{array}{l}\text { Hong Kong, China } \\
2001,2004^{[18,19]}\end{array}$ & $\begin{array}{c}\text { Men: } 153 \\
\text { Women: } 106 \\
\text { (Age: } 30-60 \text { years) }\end{array}$ & $\begin{array}{c}\text { Men: } 8.8 \% \\
\text { Women: } 3.7 \%\end{array}$ & $\begin{array}{c}\text { Men: } 5.3 \% \\
\text { Women: } 1.2 \%\end{array}$ & $\begin{array}{c}\text { Men: } 4.1 \% \\
\text { Women: } 2.1 \%\end{array}$ \\
\hline Korea $2004^{[20]}$ & $\begin{array}{c}\text { Men: } 309 \\
\text { Women: } 148 \\
\text { (Age: } 40-69 \text { years) }\end{array}$ & $\begin{array}{c}\text { Men: } 27 \% \\
\text { Women: } 16 \%\end{array}$ & $\begin{array}{c}\text { Men: } 10.1 \% \\
\text { Women: } 4.7 \%\end{array}$ & $\begin{array}{c}\text { Men: } 4.5 \% \\
\text { Women: } 2.1 \%\end{array}$ \\
\hline India $2004^{[21]}$ & $\begin{array}{c}\text { Men: } 250 \\
\text { (Age: } 35-65 \text { years) }\end{array}$ & Men: $19.5 \%$ & Men: 8.4 & Men: $7.5 \%$ \\
\hline India $2006^{[22]}$ & $\begin{array}{c}\text { Men: } 88 \\
\text { Women: } 63 \\
\text { (Age: } 30-60 \text { years) }\end{array}$ & $\begin{array}{c}\text { Men: } 19.7 \% \\
\text { Women: } 7.4 \%\end{array}$ & $\mathrm{n} / \mathrm{a}$ & $\begin{array}{c}\text { Men: } 4.9 \% \\
\text { Women: } 2.1 \%\end{array}$ \\
\hline
\end{tabular}

AHI, apnea-hypopnea index

Table 2: Comparison of anthropometric measurements of non-obese and obese subjects with obstructive sleep apnea

\begin{tabular}{|l|c|c|c|}
\hline Parameter & Group & Mean \pm SD & P Value \\
\hline \multirow{2}{*}{ BMI $\left(\mathrm{kg} / \mathrm{m}^{2}\right)$} & Non obese & $27.0 \pm 2.1$ & \multirow{2}{*}{$0.000^{\mathrm{a}}$} \\
\cline { 2 - 3 } & Obese & $36.5 \pm 3.2$ & \\
\hline \multirow{2}{*}{ Neck circumference $(\mathrm{cm})$} & Non obese & $38.3 \pm 3.2$ & \multirow{2}{*}{$0.000^{\mathrm{a}}$} \\
\cline { 2 - 3 } & Obese & $42.0 \pm 2.6$ & \\
\hline \multirow{2}{*}{ Waist circumference $(\mathrm{cm})$} & Non obese & $96.0 \pm 8.6$ & \multirow{2}{*}{$0.000^{\mathrm{a}}$} \\
\cline { 2 - 3 } & Obese & $107.2 \pm 7.3$ & \\
\hline \multirow{2}{*}{ Hip circumference $(\mathrm{cm})$} & Non obese & $100.2 \pm 8.7$ & \multirow{2}{*}{$0.002^{\mathrm{a}}$} \\
\cline { 2 - 3 } & Obese & $108.4 \pm 6.3$ & \\
\hline \multirow{2}{*}{ Thyromental distance $(\mathrm{cm})$} & Non obese & $59.1 \pm 5.2$ & \multirow{2}{*}{$0.000^{\mathrm{a}}$} \\
\cline { 2 - 3 } & Obese & $67.4 \pm 3.3$ & \\
\hline \multirow{2}{*}{ Mallampati score } & Non obese & $2^{\mathrm{c}} \pm(1 \text { to } 3)^{\mathrm{d}}$ & \multirow{2}{*}{$0.053^{\mathrm{b}}$} \\
\cline { 2 - 3 } & Obese & $3^{\mathrm{c}} \pm(2 \text { to } 3)^{\mathrm{d}}$ & \\
\hline
\end{tabular}

${ }^{\mathrm{a}}$ Unpaired $t$-test; ${ }^{\mathrm{b}}$ Mann Whitney U test/ Wilcoxon Rank Sum test; ${ }^{\mathrm{c}}$ Median; ${ }^{\mathrm{d}}$ Inter Quartile Range (IQR). Obese subject $(n=22)$ and non-obese subjects $(n=17)$.

Table 3: Comparison of polysomnographic measurements from non-obese and obese subjects with obstructive sleep apnea

\begin{tabular}{|l|c|c|c|}
\hline Parameter & Group & Mean \pm SD & $P$ value \\
\hline \multirow{2}{*}{ AHI } & Non-Obese & $16.7 \pm 5.99$ & \multirow{2}{*}{$0.000^{\mathrm{b}}$} \\
\cline { 2 - 3 } & Obese & $67.6 \pm 28.6$ & \multirow{2}{*}{$0.012^{\mathrm{a}}$} \\
\hline \multirow{2}{*}{ Snoring index (events/h) } & Non-Obese & $88.7 \pm 34.2$ & \multirow{2}{*}{$0.000^{\mathrm{b}}$} \\
\cline { 2 - 3 } & Obese & $125.4 \pm 48.0$ & \\
\hline \multirow{2}{*}{ Arousal index (events/h) } & Non-Obese & $15.3 \pm 3.5$ & \multirow{2}{*}{$0.000^{\mathrm{b}}$} \\
\cline { 2 - 3 } & Obese & $33.6 \pm 11.5$ & \\
\hline \multirow{2}{*}{$\%$ TST $<90 \% \mathrm{SaO} 2$} & Non-Obese & $11.4 \pm 2.2$ & \multirow{2}{*}{$0.000^{\mathrm{b}}$} \\
\hline & Obese & $18.5 \pm 4.3$ & \\
\hline \multirow{2}{*}{ Oxygen desaturation index (events/h) } & Non-Obese & $25.8 \pm 9.7$ & \\
\cline { 2 - 3 } & Obese & $70.2 \pm 28.7$ & \\
\hline
\end{tabular}




\begin{tabular}{|c|c|c|c|}
\hline \multirow{2}{*}{ Total sleep time } & Non-Obese & $380 \pm 36$ & \multirow{2}{*}{$0.006^{\mathrm{a}}$} \\
\hline & Obese & $348 \pm 32$ & \\
\hline \multirow{2}{*}{ Sleep stage 1 (\%TST) } & Non-Obese & $12.5 \pm 3.8$ & \multirow{2}{*}{$0.030^{\mathrm{a}}$} \\
\hline & Obese & $15.5 \pm 4.1$ & \\
\hline \multirow{2}{*}{ Sleep stage $2(\% \mathrm{TST})$} & Non-Obese & $55.5 \pm 4.5$ & \multirow{2}{*}{$0.023^{\mathrm{a}}$} \\
\hline & Obese & $59.4 \pm 5.5$ & \\
\hline \multirow{2}{*}{ Sleep stage 3 (\%TST) } & Non-Obese & $14.3 \pm 4.2$ & \multirow{2}{*}{$0.110^{\mathrm{b}}$} \\
\hline & Obese & $12.1 \pm 2.6$ & \\
\hline \multirow{2}{*}{ REM stage (\%TST) } & Non-Obese & $17.6 \pm 3.9$ & \multirow{2}{*}{$0.000^{\mathrm{a}}$} \\
\hline & Obese & $12.1 \pm 3.3$ & \\
\hline
\end{tabular}

${ }^{\mathrm{a}}$ Unpaired $t$-test; ${ }^{\mathrm{b}}$ Mann Whitney U test/ Wilcoxon Rank Sum test. Non-obese patients $(n=17)$ and obese patients $(n=22)$. Mean \%TST $<90 \% \mathrm{SaO} 2$, Mean percentage of the total sleep time spent with oxygen saturation at $<90 \%$; \% TST, percentage of the total sleep time; REM, rapid eye movement

Table 4: Comparison of study results with previous work

\begin{tabular}{|c|c|c|c|c|}
\hline Measurement & Study & Non-obese & Obese & $P$ value \\
\hline \multirow[t]{2}{*}{ Neck Circumference } & Chierakul et al. ${ }^{[12]}$ & $37.0 \pm 2.9$ & $41.6 \pm 3.5$ & $<0.001$ \\
\hline & Present study & $38.3 \pm 3.2$ & $42.0 \pm 2.6$ & $<0.001$ \\
\hline \multirow[t]{2}{*}{ Thyromental Distance } & Chierakul et al. ${ }^{[12]}$ & $56.4 \pm 11.7$ & $61.4 \pm 11.2$ & 0.006 \\
\hline & Present study & $59.1 \pm 5.2$ & $67.4 \pm 3.3$ & $<0.0001$ \\
\hline \multirow[t]{2}{*}{ Arousal Index } & Chierakul et al. ${ }^{[12]}$ & $19.5 \pm 14.9$ & $27.1 \pm 22.4$ & $<0.001$ \\
\hline & Present study & $15.3 \pm 3.5$ & $33.6 \pm 11.5$ & $<0.0001$ \\
\hline \multirow[t]{3}{*}{ Mean AHI } & Garg et al..$^{[22]}$ & $24.36 \pm 12.17$ & $50.09 \pm 29.49$ & $<0.001$ \\
\hline & Chierakul et al. ${ }^{[12]}$ & $32.7 \pm 20.5$ & $48.7 \pm 28.1$ & $<0.001$ \\
\hline & Present study & $16.7 \pm 5.9$ & $67.5 \pm 28.5$ & $<0.001$ \\
\hline \multirow[t]{3}{*}{ Oxygen desaturation index } & Garg et al..$^{[22]}$ & $30.63 \pm 15.63$ & $48.32 \pm 13.08$ & $<0.001$ \\
\hline & Chierakul et al. ${ }^{[12]}$ & $24.6 \pm 23.5$ & $51.6 \pm 34.2$ & $<0.001$ \\
\hline & Present study & $25.8 \pm 9.7$ & $70.2 \pm 28.7$ & $<0.0001$ \\
\hline \multirow[t]{2}{*}{$\%$ TST with $\mathrm{SaO} 2<90 \%$} & Chierakul et al. ${ }^{[12]}$ & $4.7 \pm 7.2$ & $26.3 \pm 27.4$ & $<0.001$ \\
\hline & Present study & $11.4 \pm 2.2$ & $18.5 \pm 4.3$ & $<0.0001$ \\
\hline \multirow[t]{2}{*}{ Total sleep time } & Garg et al. ${ }^{[22]}$ & $333.59 \pm 78.36$ & $313.45 \pm 58.83$ & 0.19 \\
\hline & Present study & $380.0 \pm 36.0$ & $348.0 \pm 342.0$ & 0.006 \\
\hline \multirow[t]{2}{*}{ N1 stage } & Antczak et al. ${ }^{[23]}$ & $21.1 \pm 10.4$ & $33.3 \pm 13.1$ & 0.02 \\
\hline & Present study & $12.5 \pm 3.8$ & $15.5 \pm 4.1$ & 0.030 \\
\hline \multirow[t]{2}{*}{ N2 stage } & Antczak et al. ${ }^{[23]}$ & $36.0 \pm 10.4$ & $31.2 \pm 12.0$ & 0.72 \\
\hline & Present study & $55.5 \pm 4.5$ & $59.4 \pm 5.5$ & 0.022 \\
\hline \multirow[t]{2}{*}{ N3 stage } & Antczak et al. ${ }^{[23]}$ & $14.5 \pm 9.8$ & $7.6 \pm 11.1$ & 0.03 \\
\hline & Present study & $14.3 \pm 4.2$ & $12.1 \pm 2.6$ & 0.045 \\
\hline \multirow[t]{2}{*}{ REM stage } & Antczak et al. ${ }^{[23]}$ & $8.5 \pm 4$ & $5.3 \pm 4.5$ & $<0.05$ \\
\hline & Present study & $17.6 \pm 3.9$ & $12.1 \pm 3.0$ & $<0.0001$ \\
\hline
\end{tabular}

AHI, apnea-hypopnea index; \% TST $<90 \% \mathrm{SaO} 2$, percentage of the total sleep time spent with oxygen saturation at $<90 \%$; REM, rapid eye movement 


\section{Discussion}

Here, we found that the OSA of obese subjects was significantly more severe than the OSA of non-obese subjects according to various parameters such as the AHI, oxygen desaturation indices, snoring index, arousal index, sleep stages, and sleep efficiency. Additionally, the severity of OSA increased with the level of obesity. Of the non-obese subjects with OSA, most of them had structural abnormalities including a lower thyromental distance than obese subjects with OSA, and the non-obese subjects had Class II and Class III abnormalities according to the Mallampati scores. Non of the non-obese subjects with OSA had class IV abnormalities while 18\% of the obese subjects with OSA did.. Previous studies in obese subjects have linked the etiology of OSA to anatomical alterations that predispose these individuals to upper airway obstruction during sleep. The findings of the present study were similar to the results of other studies and such similarities are summarized in Table 4.

There are some potential limitations to this study. One such limitation is that we used anthropometric measurements such as the neck circumference, thyromental distance, and Mallampati score for the cephalometric analyses despite the availability of multiple imaging techniques including cephalometric radiography, computed tomography, magnetic resonance imaging, and fluoroscopy. However, we chose to use the abovementioned anthropometric measurements rather than imaging, as they are easy and inexpensive to perform and correlate well with the severity of OSA. Another limitation is our small sample size. The findings of the present study need to be confirmed using a larger sample size.

In conclusion, OSA was more common in obese subjects than it was in non-obese subjects. However, some non-obese subjects also had OSA, which is contrary to an earlier theory that suggested OSA is confined only to obese subjects. Therefore, when a non-obese person presents with the clinical characteristics of OSA, the diagnostic possibility should not be under estimated and should be evaluated thoroughly.

\section{References}

1. Strollo PJ Jr, Rogers RM. Obstructive sleep apnea. N. Engl. J. Med. 1996; 334: 99-104.

2. Haslam DW, James WP. Obesity. Lancet 2005; 366: 1197-1209.

3. Ng M, Fleming T, Robinson M, Thomson B, Graetz N, Margono C, et al. Global, regional, and national prevalence of overweight and obesity in children and adults during 1980-2013: a systematic analysis for the Global Burden of Disease Study 2013. Lancet 2014; 384: 766-781.

4. Strohl KP, Redline S. Recognition of obstructive sleep apnea. Am. J. Respir. Crit. Care Med. 1996; 154: 279-289.

5. Guilleminault C, Tilkian A, Dement WC. The sleep apnea syndromes. Annu. Rev. Med. 1976; 27: 465-484.

6. Sakakibara H, Tong M, Matsushita K, Hirata M, Konishi Y, Suetsugu S. Cephalometric abnormalities in non-obese and obese patients with obstructive sleep apnoea. Eur. Respir. J. 1999; 13: 403-410.

7. Chierakul N, Chaipattarapol C, Ruttanaumpawan P, Nana A, Naruman C, Tangchityongsiva S. Comparison of clinical and polysomnographic characteristics of non-obese and obese patients with obstructive sleep apnea. J. Med. Assoc. Thai. 2007; 90 Suppl 2: 48-53.

8. Practice parameters for the indications for polysomnography and related procedures. Polysomnography Task Force, American Sleep Disorders Association Standards of Practice Committee. Sleep 1997; 20: 40622.

9. Johns MW. A new method for measuring daytime sleepiness: The Epworth sleepiness scale. Sleep 1991; 14: 540-545

10. Nuckton TJ, Glidden DV, Browner WS, Claman DM. Physical examination: 
Mallampati score as an independent predictor of OSA. Sleep 2006; 29: 903908.

11. Berry RB, Budhiraja R, Gottlieb DJ, Gozal D, Iber C, Kapur VK, et al. Rules for scoring respiratory events in sleep: update of the 2007 AASM Manual for the Scoring of Sleep and Associated Events. Deliberations of the Sleep Apnea Definitions Task Force of the American Academy of Sleep Medicine. J. Clin. Sleep Med. 2012; 8: 597-619

12. Ruehland WR, Rochford PD, O'Donoghue FJ, Pierce RJ, Singh P, Thornton AT. The new ASSM criteria for scoring hypoapnoeas: impact on the apnoea and hypoapnoea index. Sleep 2009; 32: 150-157.

13. Young T, Palta M, Dempsey J, Skatrud J, Weber S, Badr S. The occurrence of sleepdisordered breathing among middle-aged adults. N. Engl. J. Med. 1993; 328: 12301235

14. Durán J, Esnaola S, Rubio R, Iztueta Á. Obstructive sleep apnea-hypopnea and related clinical features in a populationbased sample of subjects aged 30 to $70 \mathrm{yr}$. Am. J. Respir. Crit. Care Med. 2001; 163: 685-689.

15. Bixler EO, Vgontzas AN, Lin HM, Ten Have $\mathrm{T}$, Rein J, Vela-Bueno A, et al. Prevalence of sleep-disordered breathing in women. Am. J. Respir. Crit. Care Med. 2001; 163: 608-613.

16. Bixler EO, Vgontzas AN, Ten Have T, Tyson K, Kales A. Effects of age on sleep apnea in men: I. Prevalence and severity. Am. J. Respir. Crit. Care Med. 1998; 157: 144-148.

17. Bearpark H, Elliott L, Grunstein R, Cullen S, Schneider H, Althaus W, et al. Snoring and sleep apnea. A population study in Australian men. Am. J. Respir. Crit. Care Med. 1995; 151: 1459-1465.
18. Ip MS, Lam B, Lauder IJ, Tsang KW, Chung KF, Mok YW, et al. A community study of sleep-disordered breathing in middle-aged Chinese men in Hong Kong. Chest 2001; 119: 62- 69.

19. Kim J, In K, Kim J, You S, Kang K, Shim $\mathrm{J}$, et al. Prevalence of sleep-disordered breathing in middle-aged Korean men and women. Am. J. Respir. Crit. Care Med. 2004; 170: 1108-1113.

20. Udwadia ZF, Doshi AV, Lonkar SG, Singh CI. Prevalence of sleep-disordered breathing and sleep apnea in middle-aged urban Indian men. Am. J. Respir. Crit. Care Med. 2004; 169: 168-173.

21. Sharma SK, Kumpawat S, Banga A, Goel A. Prevalence and risk factors of obstructive sleep apnea syndrome in a population of Delhi, India. Chest 2006; 130: 149-156.

22. Garg R, Singh A, Prasad R, Saheer S, Jabeed P, Verma R. A comparative study on the clinical and polysomnographic pattern of obstructive sleep apnea among obese and non-obese subjects. Ann. Thorac. Med. 2012; 7: 26-30.

23. Antczak J, Horn B, Richter A, Jernajczyk W, Bodenschatz R, W Schmidt EW. The influence of obesity on sleep quality in male sleep apnea patients before and during therapy. J. Physiol. Pharmacol. 2008; 59 Suppl 6: 123-134. 